\title{
ПЕРСПЕКТИВНІСТЬ ЗАСТОСУВАННЯ ГУСТОГО ЕКСТРАКТУ ЗІ ШПИНАТУ ГОРОДНЬОГО ЛИСТЯ ЯК МЕМБРАНОПРОТЕКТОРНОГО ЗАСОБУ ЗА УМОВ ТОКСИЧНОГО ГЕПАТИТУ
}

\author{
А. Я. Никифрорук ${ }^{1}$, Л. С. Фіра², П. Г. Лихацький \\ ДВНЗ «Ужгородський національний університет» ${ }^{1}$ \\ Тернопільський національний медичний університет імені І. Я. Горбачевського \\ мОЗ України ${ }^{2}$ \\ ludafira@ukr.net
}

\section{ІНФОРМАЦІЯ}

Надійшла до редакції / Received: 03.09.2019

Після доопрацювання / Revised: 09.09.2019

Прийнято до друку / Accepted: 10.09.2019

\section{Ключові слова:}

білі щури;

тетрахлорметан;

густий екстракт зі шпинату

городнього листя;

силімарин;

мембранопротекторні

властивості.
АНОТАЦІЯ

Мета роботи. Дослідити мембранопротекторні властивості густого екстракту зі шпинату городнього листя за умов токсичного ураження печінки тетрахлорметаном.

Матеріали і методи. Експерименти виконано на білих щурах-самцях, яким моделювали токсичний гепатит шляхом ураження печінки тетрахлорметаном (в дозі 1,0 мл/кг маси тіла тварин). Густий екстракт зі шпинату городнього листя використовували у дозі 150 мг/кг маси тіла, препарат порівняння силімарин у дозі 100 мг/кг маси тіла. Евтаназію щурів проводили під тіопенталовим наркозом на 4-ту, 7-му та 10-ту доби експерименту з дотриманням усіх правил Конвенції із захисту хребетних тварин. Активність мембранодеструктивних процесів оцінювали за аланін- та аспрататамінотрансферазною, гаммаглутамілтранспептидазною активністю та еритроцитарним індексом інтоксикації. Достовірність результатів встановлювали за допомогою параметричного (за Стьюдентом) та непараметричного (Вілкоксоном) критеріями. Достовірними вважали зміни при р $\leq 0,05$.

Результати й обговорення. Встановлено, що ураження щурів тетрахлорметаном призводить до вірогідного підвищення у сироватці крові активності амінотрансорераз та гамма-глутамілтранспептидази у всі терміни дослідження. До кінця експерименту (10-та доба) активність АлАТ підвищилась у 2,6 раза, АсАТ - у 2,7 раза та ГГТП - у 5,7 раза. У печінці щурів спостерігалось прогресуюче зниження активності ензимів. Найбільшого зниження зазнала активність ГГТП та АсАТ (у 2 рази нижче рівня інтактного контролю). У крові щурів, уражених тетрахлорметаном, спостерігали підвищення відсотка проникнення еритроцитарних мембран, який на 10-ту добу розвитку гепатиту на 33,5 \% перевищував норму. Густий екстракт зі шпинату городнього листя привів до зниження активності органоспецифрічних ензимів у сироватці крові (АлАТ у 1,9 раза щодо інтактного контролю, АсАТ на 72 \% та ГГТП - у 2,9 раза). Проникність еритроцитарної мембрани після введення в організм уражених щурів густого екстракту зі шпинату городнього листя знизилась у 2 рази.

Висновки. В експерименті на щурах з тетрахлорметановим ураженням печінки встановлено позитивний вплив густого екстракту зі шпинату городнього листя на показники проникності плазматичних мембран

ISSN 2312-0967. Фармацевтичний часопис. 2019. № 3 
Фармакологічні дослідження біологічно активних речовин Pharmacological researches of biologically active substances

гепатоцитів та еритроцитів (активність амінотрансорераз та гаммаглутамілтранспептидази, відсоток проникності еритроцитарної мембрани), які після введення в уражений організм екстракту зазнали достовірного зниження у сироватці крові. Це підтверджує мембранопротекторні властивості даного засобу, що робить перспективним подальші дослідження його фрармакологічної активності.

Вступ. Підвищення частоти отруєнь хімічними речовинами супроводжується збільшенням абсолютної кількості випадків хімічного ураження печінки. До ксенобіотиків, що надходять у процесі життєдіяльності до організму людини і тварин, і здатних зумовлювати ураження печінки, належать промислові отрути, пестициди, канцерогени, синтетичні лікарські речовини, хімічна продукція побутового призначення тощо [1, 2, 3, 4].

Одним із основних показників активності патологічного процесу в печінці є цитоліз, що виникає внаслідок порушення структури клітин печінки, насамперед, гепатоцитів. Іноді пошкоджуються тільки клітинні мембрани, частіше - ще й цитоплазма, а також окремі клітини в цілому. Головним розладом вважають порушення проникності клітинних мембран. Зазвичай на початкових стадіях цитолізу змінюється стан ліпідного шару мембран (внаслідок активації процесів ліпопероксидації), і мембрана гепатоцита стає більш проникною для ряду речовин, насамперед, для внутрішньоклітинних ензимів [5, 6].

Неухильне зростання захворюваності на гострі та хронічні гепатити в усьому світі, у тому числі в Україні, стимулює розробку та вивчення ефективності засобів для лікування захворювань печінки, 80 \% із них, які застосовуються в клінічній практиці, мають рослинне походження, тобто є фрітозасобами [7, 8, 9].

Авторами встановлено $[10,11,12]$, що в основі гепатопротекторних ефектів фрітопрепаратів, які містять діючу речовину силімарин, лежить їх антиоксидантна дія та стабілізація біомембран.

Нашу увагу, як потенційний антиоксидант, привернув густий екстракт із листя шпинату городнього, виготовлений науковцями НФаУ на кафредрі хімії природних сполук.

Шпинат городній (Spinacia oleracea L.) трав'яниста рослина, представник роду Шпинат (Spinacia), родини Амарантові (Amaranthaceae). Родом із південно-західної Азії, а зараз один 3 найпоширеніших та поживних видів овочевої зелені в усьому світі. За даними літератури, для шпинату характерна антиоксидантна, протизапальна, гепатопротекторна, протипухлинна дії, що зумовлено наявністю фенольних сполук у його складі $[13,14]$. Крім того, він містить багато таких вітамінів, як вітамін А, вітамін C, вітамін E, фролієву кислоту та таких мінералів, як магній, манган, орерум та кальцій. Шпинат також $€$ джерелом хлорофрілів та каротиноїдів, які необхідні для організму людини [15] та зумовлюють прояв антиоксидантного ефректу.
Аналізуючи дані літератури, ми поставили за мету дослідити мембранопротекторні властивості густого екстракту зі шпинату городнього листя за умов токсичного ураження печінки тетрахлорметаном.

Матеріали і методи. В експерименті використано 60 білих щурів-самців, які утримувались на стандарному раціоні віварію Тернопільського національного медичного університету імені І. Я. Горбачевського.

Для дослідження ефективності застосування густого екстракту зі шпинату як мембранопротекторного засобу обрали модель ураження печінки тварин тетрахлорметаном, який вводили дворазово (через день) у вигляді 50 \% олійного розчину в дозі 1,0 мл/кг маси тіла тварин [16]. Попередньо провели експерименти зі встановлення мінімально діючої дози густого екстракту зі шпинату листя - 150 мг/кг, яку в подальшому використали в дослідженнях [17]. Густий екстракт зі шпинату городнього (ГЕШГ) листя отримано методом ремацерації на кафедрі хімії природних сполук НФаУ під керівництвом проф. Журавель І. О. Препаратом порівняння обрано еталонний гепатопротектор рослинного походження силімарин під торговою маркою «Карсил» виробництва фрірми «Sopharma» (Болгарія), який щурам вводили у вигляді 1 \% крохмальної суспензії у дозі 100 мг/кг маси тіла.

Дослідні тварини були розділені на чотири групи: 1-ша - інтактний контроль (6 щурів); 2-га - щури, уражені тетрахлорметаном (18 щурів); 3-тя - уражені тетрахлорметаном щури після застосування густого ектракту зі шпинату (18 щурів); 4-та - уражені тетрахлорметаном щури після застосування силімарину (18 щурів).

Евтаназію щурів проводили під тіопенталовим наркозом на 4-ту, 7-му та 10-ту доби експерименту. При проведенні експерименту дотримувались усіх правил Конвенції із захисту хребетних тварин [18].

Для досліджень використовували сироватку крові та печінку дослідних щурів. Кров забирали із серця тварин, яку центрифугували при частоті обертання 1100 g впродовж 30 хв. Отриману сироватку крові (надосадову рідину) використовували для проведення досліджень. Із печінки виготовляли $10 \%$ водний гомогенат за допомогою гомогенізатора магнітного Silent Crusher S після попередньої перфрузії 250 мг печінки 3 2,5 мл фрізіологічного розчину. Активність мембранодеструктивних процесів після введення коригуючих чинників оцінювали за аланін- та аспрататамінотрансферазною активністю (АлАТ та АсАТ) [19,

ISSN 2312-0967. Pharmaceutical review. 2019. № 3 
Фармакологічні дослідження біологічно активних речовин Pharmacological researches of biologically active substances

20], гамма-глутамілтранспептидазною активністю (ГГТП) [21] та еритроцитарним індексом інтоксикації (EII) [22]. Для статистичної обробки даних використовували параметричні (за Стьюдентом) та непараметричні (Вілкоксоном) методи дослідження. Вірогідні зміни вважали при р $\leq 0,05$ [23].

Результати й обговорення. Однією з причин зміни проникності клітинних мембран під дією тетрахлорметану може бути токсичний вплив його метаболітів на структурні компоненти саме мембран - як ліпідні, так і протеїнові.

Найефективніше ступінь ураження клітинних мембран відображається співвідношенням активності внутрішньоклітинних ензимів у клітині та поза ії межами, оскільки в нормі лише незначна кількість внутрішньоклітинних ензимів знаходиться в сироватці крові. Рівень активності ензимів корелює зі ступенем пошкодження, який може виражатися від патологічного посилення проникності мембрани клітин до некрозу. Найбільшої уваги заслуговують органоспецифічні, або індикаторні ензими, які є специфрічними тільки для певного типу тканин [24].

На пошкодження структури мембран клітин за дії токсикантів вказує зміна активності органоспецифрічних ензимів АлАТ і АсАТ у сироватці крові щурів. Оскільки досліджувані ензими локалізуються, відповідно, в цитозолі та лізосомах гепатоцитів, то за змінами їх активності можна оцінити ступінь пошкодження плазматичних і цитоплазматичних мембран клітин печінки [19] (табл. 1).

Найвища активність АлАТ у сироватці крові уражених щурів зареєстрована на 7-му добу дослідження, яка у 2,7 раза перевищувала рівень інтактного контролю. Застосування ГЕШГ у цей термін призвело до зниження активності ензиму в 1,2 раза. У терміні до- слідження 10 діб ефрективність екстракту проявилась значно більше, активність АлАТ знизилась у 1,9 раза відносно рівня контрольної патології. Ефективність застосування силімарину була дещо вищою і до кінця експерименту активність дослідного ензиму в сироватці крові уражених тетрахлорметаном тварин знизилась у 2,3 раза.

Враховуючи, що АлАТ є маркерним ензимом печінки, ми дослідили їі активність саме в цьому органі. У токсикованих щурів даний показник прогресуюче знижувався і досяг до кінця експерименту максимально низького значення (у 2 рази нижче інтактного контролю). Застосування обох коригуючих чинників (ГЕШГ та силімарину) призвело до відновлення активності ензиму в печінці тварин. У щурів, які отримували ГЕШГ, активність АлАТ підвищилась у 1,9 раза, після застосування силімарину - в 2 рази.

Досліджено активність АсАТ у сироватці крові та печінці уражених тварин та після застосування дослідного екстракту та силімарину.

Встановлено, що після введення щурам тетрахлорметану в сироваті крові активність ензиму підвищувалась від 214 \% у терміні 4 доба після ураження до $273 \%$ через 10 діб від початку експерименту (рис. 1).

Дослідний екстракт призвів до зниження даного показника у сироватці крові протягом усього експерименту. Вірогідні зміни $(p \leq 0,05)$ спостерігали у терміні 7 та 10 діб від початку дослідження. У кінцевому терміні активність АсАТ знизилась на $72 \%$ під впливом екстракту та на 125 \% після застосування силімарину.

У печінці уражених тетрахорметаном тварин спостерігали зворотні зміни. В останній термін дослідження активність АсАТ знизилась на 40 \% щодо рів-

\section{Таблиця 1}

Активність аланінамінотрансорерази у сироватці крові та печінці щурів, уражених тетрахлорметаном, та після застосування густого екстракту зі шпинату городнього $(\mathrm{M} \pm \mathrm{m} ; \mathrm{n}=6)$

\begin{tabular}{|c|c|c|c|}
\hline \multirow{2}{*}{ Групи тварин } & \multicolumn{3}{|c|}{ Терміни дослідження, доби } \\
\hline & 4 доба & 7 доба & 10 доба \\
\hline & \multicolumn{3}{|c|}{ Сироватка крові, мкмоль/л год } \\
\hline Інтактний контроль (ІК) & \multicolumn{3}{|c|}{$2,90 \pm 0,21$} \\
\hline Уражені ССІ (контрольна патологія, КП) & $4,61 \pm 0,27^{*}$ & $7,85 \pm 0,24^{*}$ & $7,49 \pm 0,34^{*}$ \\
\hline Уражені $\mathrm{CCl}_{4}+$ ГЕШГ & $4,24 \pm 0,24$ & $6,56 \pm 0,26$ ** & $3,90 \pm 0,17^{\star *}$ \\
\hline \multirow[t]{2}{*}{ Уражені $\mathrm{CCl}_{4}+$ силімарин } & $3,67 \pm 0,25^{\star \star}$ & $4,25 \pm 0,31^{\star *}$ & $3,27 \pm 0,15^{\star *}$ \\
\hline & \multicolumn{3}{|c|}{ Печінка, мкмоль/кг год } \\
\hline Інтактний контроль (ІК) & \multicolumn{3}{|c|}{$9,43 \pm 0,50$} \\
\hline 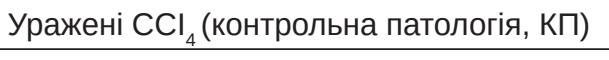 & $6,18 \pm 0,36^{*}$ & $4,88 \pm 0,34^{*}$ & $4,67 \pm 0,30^{\star}$ \\
\hline Уражені $\mathrm{CCl}_{4}+$ ГЕШГ & $6,71 \pm 0,29$ & $7,39 \pm 0,32^{\star *}$ & $8,84 \pm 0,35^{\star *}$ \\
\hline Уражені ССІ ${ }_{4}$ + силімарин & $8,22 \pm 0,29 * \star$ & $8,78 \pm 0,53^{\star \star}$ & $9,30 \pm 0,50 * *$ \\
\hline
\end{tabular}

Примітка: тут і в наступних таблицях * - вірогідні зміни між щурами інтактного контролю та щурами, ураженими тетрахлорметаном; ** - вірогідні зміни між ураженими щурами та щурами, які піддавались корекції.

ISSN 2312-0967. Фармацевтичний часопис. 2019. № 3 
Фармакологічні дослідження біологічно активних речовин Pharmacological researches of biologically active substances

$\%$

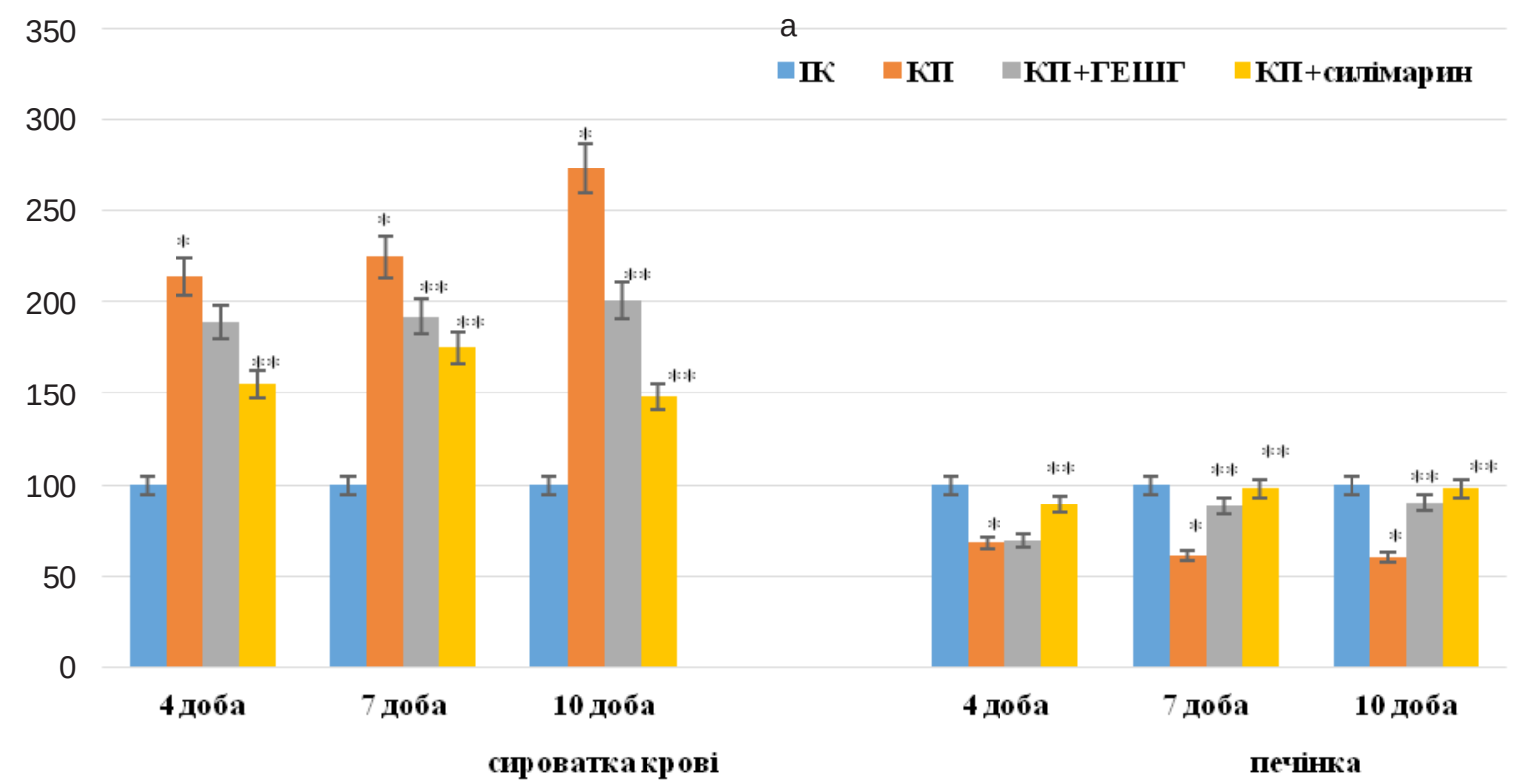

Примітка: тут і на наступних рисунках: * вірогідні зміни між щурами інтактного контролю та щурами, ураженими тетрахлорметаном; ** - вірогідні зміни між ураженими щурами та щурами, які піддавались корекції.

Рис. 1. Активність АсАТ у сироватці крові та печінці щурів, уражених тетрахлорметаном, та після застосування коригуючих чинників, \%.

ня інтактного контролю. Застосування ГЕШГ призвело до підвищення ензимної активності у печінці на $30 \%$, силімарину - на $38 \%$.

Отже, обидва чинники виявились ефективними, після їх застосування активність АсАТ збільшувалась у печінці та знижувалась у сироватці крові уражених тетрахлорметаном тварин. Однією із причин цього може бути відновлення проникності мембран гепатоцитів. Очевидно, дослідний екстракт за рахунок БАР, які в ньому містяться (фенольні сполуки, геміцелюлоза та жирні кислоти) $[25,26]$, сприяє відновленню структури плазматичних мембран клітин.

Суттєвих змін зазнавала активність ще одного органоспецифічного ензиму печінки (маркера некрозу) - гамма-глутамілтранспептидази.

ГГТП - мікросомальний ензим, що бере участь в обміні амінокислот, каталізуючи перенесення у-глутамінового залишку з пептиду (зазвичай глутатіону) на амінокислоту, інший пептид чи воду. Зростання активності ГГТП спостерігається при ураженнях гепатобіліарної системи (гепатитах, холестазі, холангіті), а також при жировому переродженні печінки. Підвищенння активності ензиму викликають різні ксенобіотики, зокрема ліки, здатні активувати оксидазну активність мікросомальних ензимів, а також будь-який оксидативний стрес [27].

При дослідженні активності ГГТП у сироватці щурів, уражених тетрахлорметаном, спостерігали її підвищення (табл. 2). Максимальний показник спостері- гали на 10-ту добу експерименту (в 5,7 раза перевищувало норму).

Вірогідного зниження $(p \leq 0,05)$ зазнав даний показник у сироватці крові в усі терміни експерименту після застосування силімарину. ГЕШГ ефективний вплив на активність ензиму проявив на 7-му та 10-ту доби дослідження. Спостерігали зниження активності ГГТП у 1,6 раза та 2,9 раза відповідно.

У печінці уражених щурів активність ензиму прогресуюче знижувалась протягом усього експерименту і в 2 рази була нижче рівня інтактного контролю у кінці дослідження.

Більш ефективним виявилось застосування силімарину протягом усіх термінів експерименту. ГЕШГ вірогідно підвищував активність ензиму у печінці на 7-му та 10-ту доби (в 1,3 та 1,7 раза відповідно).

Для оцінки функціонального стану цитоплазматичних мембран еритроцитів важливе значення має визначення відсотку їі проникності, оскільки високий його рівень вказує на деградацію гліцерофросфоліпідів біліпідного шару мембрани, що призводить до підвищення індексу сореричності еритроцитарної клітини, зменшення еластичності, збільшення осмотичної крихкості та фррагментації самої мембрани. Внаслідок цього відбувається розлад функції проникності клітинної мембрани до різних речовин [28].

Доцільним було дослідити відсоток проникності еритроцитарних мембран у щурів за умов їхнього отруєння тетрахлорметаном та після застосування коригуючих чинників.

ISSN 2312-0967. Pharmaceutical review. 2019. № 3 
Фармакологічні дослідження біологічно активних речовин Pharmacological researches of biologically active substances

\section{Таблиця 2}

Активність гамма-глутамілтранспептидази у сироватці крові та печінці щурів, уражених тетрахлорметаном, та

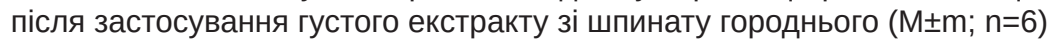

\begin{tabular}{|c|c|c|c|}
\hline \multirow{2}{*}{ Групи тварин } & \multicolumn{3}{|c|}{ Терміни дослідження, доби } \\
\hline & 4 доба & 7 доба & 10 доба \\
\hline & \multicolumn{3}{|c|}{ Сироватка крові, мкмоль/л } \\
\hline Інтактний контроль (ІК) & \multicolumn{3}{|c|}{$0,180 \pm 0,009$} \\
\hline 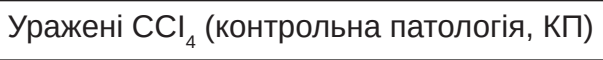 & $0,82 \pm 0,07^{*}$ & $0,99 \pm 0,08^{*}$ & $1,03 \pm 0,06^{*}$ \\
\hline Уражені ССІ + ГЕШГ & $0,72 \pm 0,04$ & $0,61 \pm 0,04^{\star *}$ & $0,34 \pm 0,03^{\star *}$ \\
\hline \multirow[t]{2}{*}{ Уражені $\mathrm{CCl}_{4}$ + силімарин } & $0,51 \pm 0,04^{\star \star}$ & $0,58 \pm 0,04^{* *}$ & $0,25 \pm 0,02^{\star *}$ \\
\hline & \multicolumn{3}{|c|}{ Печінка, мкмоль/кг } \\
\hline Інтактний контроль (ІК) & \multicolumn{3}{|c|}{$0,95 \pm 0,05$} \\
\hline Уражені ССІ (контрольна патологія, КП) & $0,68 \pm 0,04^{*}$ & $0,53 \pm 0,02^{*}$ & $0,47 \pm 0,03^{*}$ \\
\hline Уражені ССl + ГЕШГ & $0,70 \pm 0,03$ & $0,71 \pm 0,02^{\star *}$ & $0,82 \pm 0,03^{\star *}$ \\
\hline Уражені $\mathrm{CCI}_{4}+$ силімарин & $0,85 \pm 0,03^{\star \star}$ & $0,89 \pm 0,02^{\star \star}$ & $0,93 \pm 0,02^{\star \star}$ \\
\hline
\end{tabular}

Ми дослідили Ell у токсикованих щурів після потрапляння до організму тетрахлорметнау та застосування ГЕШГ та силімарину.

Ураження печінки щурів токсичними дозами $\mathrm{CC}_{4}$ призвело до підвищення проникності еритроцитарних мембран, причому із подовженням терміну дослідження відсоток проникності прогресуюче збільшувався - на 4-ту добу експерименту на 23 \%, на 7-му добу - на 27,5 \% і на 10-ту добу 33,5 \% (рис. 2).

Обидва засоби (досліджуваний ГЕШГ та силімарин) ефективний вплив проявили на даний показник із 7 доби дослідження. Проникність еритроцитарної мембрани вірогідно відновлювалась $(\mathrm{p} \leq 0,05)$ у термінах 7 та 10 доба експерименту. Силімарин дещо перевершував за ефрективністю екстракту зі шпинату городнього.

Очевидно, такий вплив ГЕШГ на стабілізацію проникності клітинних мембран є наслідком його антиоксидантного ефекту, що показано нами раніше [29]. Використання даного чинника призводить до зниження активності процесів ліпопероксидації та окиснювальної модифрікації протеїнів, чим зменшується токсичний вплив продуктів вільнорадикального окиснення на мембрани. Це сприяє відновленню їхньої структури та проникності.

$\%$

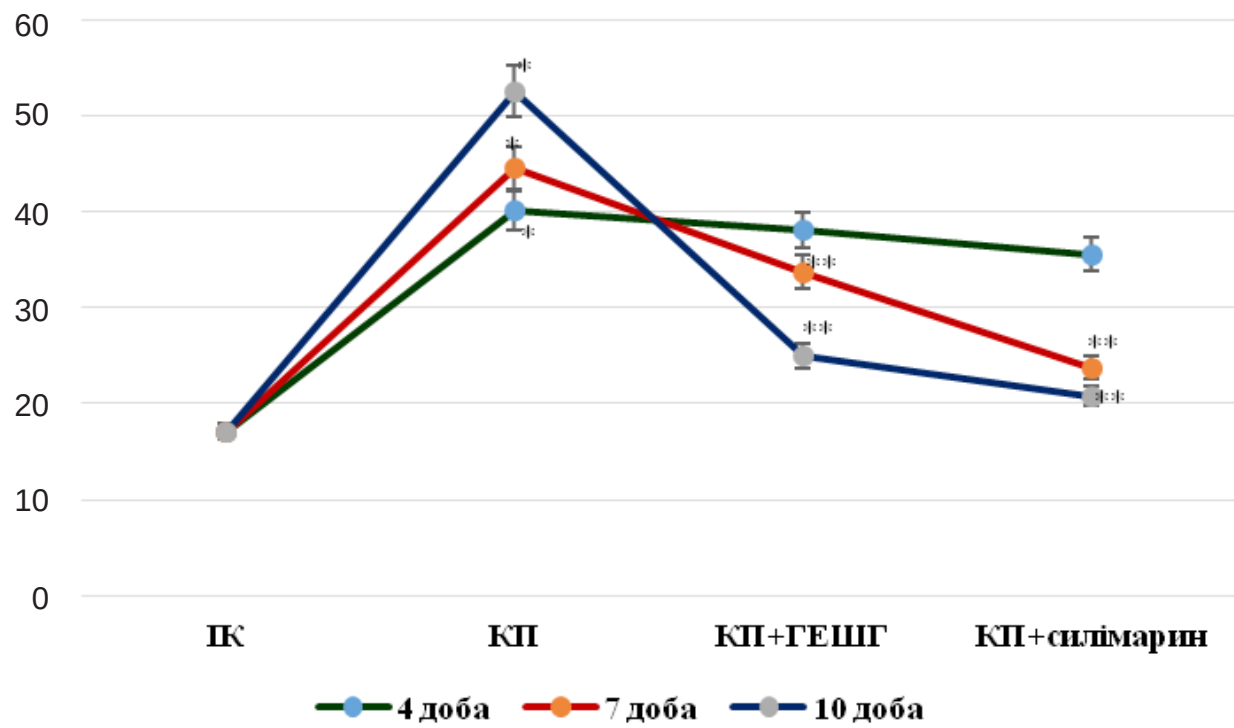

Рис. 2. Еритроцитарний індекс інтоксикації у щурів, уражених тетрахлорметаном, та після застосування коригуючих чинників, \%.

ISSN 2312-0967. Фармацевтичний часопис. 2019. № 3 
Фармакологічні дослідження біологічно активних речовин

Pharmacological researches of biologically active substances

Висновки. 1. Ураження печінки щурів тетрахлорметаном призводить до зміни проникності плазматичних мембран гепатоцитів, на що вказує підвищення у сироватці крові активності амінотрансфрераз та гамма-глутамілтранспептидази, а також зниження їх у печінці. Максимальні зміни спостерігали у кінці дослідження - на 10-ту добу експерименту.

2. В умовах тетрахлорметанового гепатиту виявлено зміни проникності еритроцитарних мембран, збільшення яких прогресуюче зростало до кінця експерименту і на 33 \% перевищувало норму.

3. Виявлено позитивний вплив густого екстракту зі шпинату городнього листя на плазматичні мембрани гепатоцитів та еритроцитів, що сприяє їх відновленню. Зіставлення ефективності застосування силімарину та екстракту зі шпинату городнього листя підтверджує мембранопротекторні властивості останнього і робить доцільним подальше вивчення його фрармакологічної активності.

\title{
THE PERSPECTIVE OF APPLYING OF DENSE SPINACH LEAVES EXTRACT (SPINACIA OLERACEA L.) AS MEMBRANE PROTECTOR IN CONDITIONS OF TOXIC HEPATITIS
}

\author{
A. Ya. Nykyforuk ${ }^{1}$, L. S. Fira², P. H. Lykhatskyi² \\ Uzhhorod National University, \\ I. Horbachevsky Ternopil National Medical University² \\ ludafira@ukr.net
}

The aim of the work. Investigation of the membrane-protective properties of the dense leafy spinach extract in conditions of toxic liver damage with tetrachloromethane.

Materials and Methods. The experiments were performed on white male rats, which were simulated toxic hepatitis by liver damage with tetrachloromethane. The toxicant was administered at a dose of $1.0 \mathrm{ml} / \mathrm{kg}$ body weight of animals. Dense spinach leaves extract was used at a dose of $150 \mathrm{mg} / \mathrm{kg}$ body weight, a drug comparison silymarin at a dose of $100 \mathrm{mg} / \mathrm{kg}$ body weight. Euthanasia of rats was performed under thiopental anesthesia on the 4th, 7th and 10th day of the experiment in compliance with all the rules of the Vertebrate Convention. The activity of membrane-destructive processes was evaluated by alanine and aspartate aminotransferase, gamma-glutamyltranspeptidase activity and erythrocyte intoxication index. Parametric (Student's) and nonparametric (Wilcoxon) methods were used for statistical data processing.

Results and Discussion. It was shown that the destruction of rats with tetrachloromethane leads to a significant increase in serum activity of aminotransferases and gamaglutamyltranspeptidase in all study periods (4, 7 and 10 days from the beginning of the experiment). In the liver of rats, there was a progressive decrease in the activity of enzymes, which is a consequence of impaired permeability of plasma membranes of hepatocytes. In the blood of rats infected with tetrachloromethane, an increase in the percentage of penetration of erythrocyte membranes was noted. Used of dense extract of spinach leaves had an effective effect on the studied parameters and slightly inferior to the drug silymarin.

Conclusions. The positive effect of the dense spinach leaf extract on the permeability indices of the plasma membranes of hepatocytes and erythrocytes, which were significantly decreased in serum after administration of the extract, was found in an experiment on rats with tetrachloromethane damage of the liver. This confirms the membrane-protective properties of this remedy, which makes it promising to further study of its pharmacological activity.

Key words: white rats; tetrachloromethane; thick leafy spinach extract; silymarin; membrane-protecting properties.

\section{ПЕРСПЕКТИВНОСТЬ ИСПОЛЬЗОВАНИЯ ГУСТОГО ЭКСТРАКТА ИЗ ШПИНАТА ОГОРОДНОГО ЛИСТЬЕВ КАК МЕМБРАНОПРОТЕКТОРНОГО СРЕДСТВА ПРИ ТОКСИЧЕСКОМ ГЕПАТИТЕ}

\author{
А. Я. Никифорук ${ }^{1}$ Л. С. Фира², П. Г. Лихацкий² \\ ГВУЗ «Ужгородский национальный университет» ${ }^{1}$ \\ Тернопольский национальный медицинский университет имени И. Я. Горбачевского МОз Украинь' \\ ludafira@ukr.net
}

Цель работы. Исследовать мембранопротекторные свойства густого экстракта из шпината огородного листьев в условиях токсического поражения печени тетрахлорметаном.

Материалы и методы. Эксперименты проведены на белых крысах-самцах, которым моделировали токсический гепатит путем поражения печени тетрахлорметаном. Токсикант вводили в дозе 1,0 мл/кг массы тела животных. Густой экстракт из шпината использовали в дозе 150 мг/кг массы тела, препарат сравнения силимарин в дозе

ISSN 2312-0967. Pharmaceutical review. 2019. № 3 
Фармакологічні дослідження біологічно активних речовин Pharmacological researches of biologically active substances

100 мг/кг массы тела. Эвтаназию крыс проводили под тиопенталовым наркозом на 4, 7 и 10 день эксперимента с соблюдением всех правил Конвенции по защите позвоночных животных. Активность мембранодеструктивных процессов оценивали по аланин- и аспрататаминотранссреразной, гамма-глутамилтранспептидазной активности и эритроцитарному индексу интоксикации. Для статистической обработки данных использовали параметрические (Стьюдента) и непараметрические (Вилкоксона) методы исследования.

Результаты и обсуждение. Установлено, что поражение крыс тетрахлорметаном приводит к достоверному повышению в сыворотке крови активности аминотрансфераз и гамма-глутамилтранспептидазы во все сроки исследования (4, 7 и 10 сутки от начала эксперимента). В печени крыс наблюдалось прогрессирующее снижение активности энзимов, что является следствием нарушения проницаемости плазматических мембран гепатоцитов. В крови крыс, пораженных тетрахлорметаном, отмечено повышение процента проникновения эритроцитарных мембран. Использованный густой экстракт из шпината огородного листьев проявил эффективное влияние на исследуемые показатели и незначительно уступал препарату силимарину.

Выводы. Поражение печени крыс тетрахлорметаном приводит к изменению проницаемости плазматических мембран гепатоцитов и эритроцитов, максимальные изменения которых отмечено в конце исследования. Сопоставление эфрфективности применения силимарина и экстракта из шпината огородного подтверждает мембранопротекторные свойства данного средства, делает перспективными дальнейшие исследования его фрармакологической активности.

Ключевые слова: белые крысы; тетрахлорметан; густой экстракт из шпината огородного листьев; силимарин; мембранопротекторные свойства.

\section{Список літератури}

1. Роль печінки у підтриманні гомеостазу організму людини за фрізіологічних та патологічних умов / Б. Г. Макар, Т. В. Процак, Н. І. Гаїна, Т. М. Антоняк // Вісник проблем біології і медицини. - 2012. - № 3. - С. 1517.

2. Влияние интоксикации четыреххлористым углеродом на показатели белкового обмена в эксперименте / М. А. Хильчук, Е. Е. Есауленко, А. А. Ладутько, И. М. Быков // XVII Конгресс «Гепатология сегодня», 19 - 21 марта 2012 г., Москва : материалы конгресса. - М., 2012. - С. 32.

3. Губергриц Н. Б. Хронические гепатиты и циррозы печени. Современные классификация, діагностика и лечение / Н. Б. Губерглиц. - К. : Віпол, 2010. - 328 с.

4. Дроговоз С. М. Современные подходы к терапии заболеваний гепатобилиарной системы / С. М. Дроговоз, Е. Г. Щекина, А. Ушакова // Провизор. - 2008. - № 8. - С. 19-22.

5. Вялов С. С. Синдром цитолиза в гастроэнтерологии: тактика ведения пациентов в общей практике / С. С. Вялов // Гастроэнтерология : приложение к журн. Consilium Medicum. - 2013. - № 1. - C. 42 - 48.

6. Перелік захворювань печінки, їх симптоми та діагностика [Електронний ресурс]. - Режим доступу до pecypcy : http://medprice.com.ua/ukr/articles/perelik zahvoryuvan pechinkii himptomi-ta-diagnostika 4708. html.

7. Гарник Т. Гепатопротекторное действие фритосредств в комплексной терапии и реабилитации больных хроническим гепатитом / Т. Гарник // Ліки України. - 2002. - № 11. - С. 2-5.

8. Гепатопротекторы: от теории к практике. / Н. Б. Губергриц, Г. Д. Фадеенко, Г.М.Лукашевич, П. Г. Фоменко. - Донецк : Лебедь, 2012. - 156 с.

9. Дегтярева И. И. Гепатопротекторы-антиоксиданты в терапии больных с хроническими дифффузыми заболеваниями печени / И. И. Дегтярева, И.Н.Скрыпник,
А. В. Невойт // Новые мед. технологии. - 2002. № 6. - C. 18-23.

10. Фармакотерапевтические эфрфекты и клинические возможности эталонного препарата силимарина / Н. Б. Губергриц, П. Г. Фоменко, Г. М. Лукашевич, О. А. Голубова // ФАРМАТЕКА. - 2012. - № 2. C. 24-31.

11. Журавльова Л. В. Порівняльна характеристика гепатопротекторних засобів: ключ до раціонального застосування / Л. В. Журавльова, О.М.Кривоносова // Сучасна гастроентерологія. - 2013. - 4 (72) - С. 3541.

12. Кучерявый Ю. А. Гепатопротекторы: рациональные аспекты применения : учебное пособие для врачей / Ю. А. Кучерявый, С. В. Морозов. - М., 2012. - 36 с.

13. Otari K. V. Spinacia oleracea I inn: a pharmacognostic and pharmacological overview / P. S. Gaikwad, R. V. Shete, K. V. Otari // International Journal of Research in Ayurveda Pharmacy. - 2010. - Vol. 1. P. 78-84.

14. Sang-Heui Ko. Antioxidant Effects of Spinach (Spinacia oleracea L.) supplementation in hyperlipidemicrats / Sang-Heui Ko, Jae-Hee Park, So-Yun Kimetal // Preventive Nutrition and Food Science. - 2014. Vol.19 (1). - P.19-26.

15. Deven Metha. Pharmacological activity of Spinacia oleracea L inn. - a complete overview / Deven Metha, Sateesh Belemkar // Asian Journal of Pharmaceutical Research and Development. - 2014. - Vol. 2 (1). P. 32-42.

16. Экспериментальная модель токсического поражения печени и способы ее коррекции / М. А. Хильчук, Е. Е. Есауленко, А. А. Ладутько, И. М. Быков // Аллергология и иммунология. - 2012. - Т. 13, № 1. C. 131.

17. Никисорук А. Я. Встановлення ефективної дози густого екстракту з листя шпинату городнього на моде-

ISSN 2312-0967. Фармацевтичний часопис. 2019. № 3 
лі токсичного ураження печінки / А. Я. Никифрорук, Л. С. Фіра, П. Г. Лихацький // Фітотерапія. Часопис. - 2018. - № 3. - С. $38-43$.

18. Gross D. Ethics in Animal-Based Research / D. Gross, R. Tolba // Eur. Surg. Res. - 2015. - Vol. 55, Issue 1-2. - C. 43 - 57. doi: 10.1159/000377721.

19. Aspartate Aminotransferase (AST/GOT) and Alanine Aminotransferase (ALT/GPT) / X. J. Huang, Y. K. Choi, H. S. Im [et al.] // Detection Techniques. Sensors (Basel). 2006. - Vol. 6(7). - P. 756-782. [PubMed].

20. Reitman S. Definition of biochemical indicators of the toxicity of liver / S. Reitman, S. Frankel // Amer. J. Clin. Path. - 1957. - No 28(1). - P. 56-60.

21. Камышников В. С. Справочник по клиникобиохимическим исследованиям и лабораторной диагностике / В. С. Камышников. - Москва : МЕДпресс-инфрорм, 2009. - 43 с.

22. Тогайбаев А. А. Способ диагностики эндогенной интоксикации / А. А. Тогайбаев, А. В. Кургузкин, И. В. Рикун // Лаб. дело. - 1988. -№ 9. - С. 22 - 24.

23. Okeh U. Statistical problems in medical research / U. Okeh // East. Afr. J. Public. Health. - 2009. - Vol. 6, Issue 1. - P. $1-7$.

24. Imlay J. A. The mismetallation of enzymes during oxidative stress / JA Imlay // Biol. Chem. - 2014. Vol. 289 (41). - P. 28121-28128. doi: 10.1074/jbc. R114.588814. [PubMed].

25. Гриненко У. В. Количественное определение фенольных соединений в листьях шпината огородного (Spinacia oleracea L.) / У. В. Гриненко,

\section{References}

1. Makar BH, Protsak TV, Hain NI, Antoniak TM. [The role of the liver in the maintenance of homeostasis of the human body under physiological and pathological conditions]. Visnyk problem biolohii i medytsyny. 2012;3: 15-17. Ukrainian.

2. Khilchuk MA, Esaulenko EE, Ladutko AA, Bykov IM. [The effect of carbon tetrachloride intoxication on protein metabolism in an experiment]. XVII Congress "Hepatology Today", 2012 March 19-21; Moscow: Materials of the Congress, 2012. p.32. Russian.

3. Gubergritz NB. Chronic hepatitis and cirrhosis. Modern classification, diagnosis and treatment [Хронические гепатиты и циррозы печени. Современные классисрикация, діагностика и лечение] Kyiv: Vipol. Russian.

4. Drogovoz SM, Shchekina EG, Ushakova GA. [Modern approaches to the treatment of diseases of the hepatobiliary system]. Provizor. 2008;8: 19-22. Russian.

5. Vyalov SS. [Syndrome of cytolysis in gastroenterology: management tactics in general practice]. Gastroenterologiya: prilozh. k zhurn. Consilium Medicum. - 2013;1: 42-48. Russian.

6. List of liver diseases, their symptoms and diagnostics [Electronic resource]. Available at: http://medprice.com. ua/eng/articles/perelik zahvoryuvan pechinkii himptomita-diagnostika 4708.html. Ukrainian.

7. Garnik T. [Hepatoprotective effect of phytosanctives in complex therapy and rehabilitation of patients with
И. А. Журавель // Роль молодёжи в развитии медицинской науки : материалы XII научнопрактической коноеренции молодых учёных и студентов ТГМУ им. Абуали ибни Сино с международным участием, посвящённой «Году молодёжи», г. Душанбе (Таджикистан), 28 апреля 2017. -Душанбе : Изд-во ТГМУ, 2017. - С. 292 - 293.

26. Гриненко У. В. Определение количественного содержания органических кислот в листьях шпината огородного (Spinacia oleracea L.) / У. В. Гриненко, И. А. Журавель // Актуальные вопросы современной медицины и фармации : материалы 69-й итоговой научно-практической конференции студентов и молодых ученых. - Витебск : ВГМУ, 2017. - С. 611 $-612$

27. Мороз Л. В. Застосування препарату Ентеросгель у комплексній терапії пацієнтів із гострими вірусними гепатитами із супутнім дисбактеріозом кишечника / Л. В. Мороз, І. Г. Палій, Т. В. Ткаченко // Внутренняя медицина. - 2008. - 1(7). - С. 11 - 18.

28. Ogawa $\mathrm{K}$. The association of elevated reactive oxygen species levels from neutrophils with low-grade inflammation in the elderly / K. Ogawa, K. Suzuki, M. Okutsu [et al.] // Immun Ageing. - 2008. - 5. - P. 1-8. doi:10.1186/1742-4933-5-13.

29. Никисрорук А. Я. Дослідження антиоксидантних властивостей екстракту зі шпинату городнього листя на моделі тетрахлорметанового ураження печінки / А. Я. Никифорук, Л. С. Фіра, П. Г. Лихацький // Мед. та клін. хімія. - 2018. - 20(4). - С. 36 - 43.

chronic hepatitis]. Liky Ukrainy. 2002;11: 2-5. Russian.

8. Gubergrits NB, Fadeenko GD, Lukashevich GM, Fomenko PG. [Hepatoprotectors: from theory to practice]. Donetsk: Swan. Russian.

9. Degtyareva II, Skrypnik IN, Neut AV. [Hepatoprotective antioxidants in the treatment of patients with chronic diffuse liver diseases]. Novye med tekhnolog. 2002; 6: 18-23. Russian.

10. Gubergrits NB, Fomenko PG, Lukashevich GM, Golubova OA. [Pharmacotherapeutic effects and clinical capabilities of the reference drug silymarin]. PHARMATEKA. 2012;2: 24-31. Russian.

11. Zhuravliova LV, Krivonosova OM. [Comparative characteristics of hepatoprotective agents: the key to rational use]. Suchasna hastroenterolohiia. 2013;4(72): 35-41. Ukrainian.

12. Kucheryavyy YuA., Morozov SV. Hepatoprotectors: rational aspects of application: textbook for doctors. [Гепатопротекторы: рациональные аспекты применения : учебное пособие для врачей] Moscow. Russian.

13. Otari KV, Gaikwad PS, Shete RV. Spinacia oleracea I inn: a pharmacognostic and pharmacological overview. International Journal of Research in Ayurveda Pharmacy. 2010;1: 78-84.

14. Sang-Heui Ko, Jae-Hee Park, So-Yun Kimetal. Antioxidant Effects of Spinach (Spinacia oleracea

ISSN 2312-0967. Pharmaceutical review. 2019. № 3 
L.) supplementation in hyperlipidemicrats. Preventive Nutrition and Food Science. 2014;19(1): 19-26.

15. Deven Metha, Sateesh Belemkar. Pharmacologica activity of Spinacia oleracea L inn.- a complete overview. Asian Journal of Pharmaceutical Research and Development. 2014;2(1): 32-42.

16. Khilchuk MA, Esaulenko EE, Ladutko AA, Bykov IM. [An experimental model of toxic liver damage and methods for its correction]. Allergologiya i Immunologiya. 2012;13(1): 131. Russian.

17. Nykyforuk AYa, Fira LS, Lykhatskyi PH. [Establishing an effective dose of a thick extract of vegetable spinach leaves on a model of liver toxicity]. Fitoterapiia. Chasopys. 2018;3: 38-43. Ukrainian.

18. Gross D, Tolba R. Ethics in animal-based research. Eur Surg Res. 2015;55(1-2): 43-57. doi: 10.1159/000377721.

19. Huang $X J$, Choi YK, Im HS, Yarimaga O, Yoon E, Kim HS. Aspartate aminotransferase (AST/GOT) and alanine aminotransferase (ALT/GPT). Detection Techniques. Sensors (Basel). 2006;6(7): 756-82. [PubMed].

20. Reitman SS., Frankel S. Definition of biochemical indicators of the toxicity of liver. Amer J Clin Path. 1957;28(1): 56-60.

21. Kamyshnikov VS. Handbook of clinical and biochemical studies and laboratory diagnostics. [Справочник по клинико-биохимическим исследованиям и лабораторной диагностике] Moscow: MEDpress-inform; 2009. Russian.

22. Togaybaev AA, Kurguzkin AV, Rikun I. [A method for the diagnosis of endogenous intoxication]. Lab delo. 1988;9: 22-4. Russian.
23. Okeh U. Statistical problems in medical research. East Afr J Public Health. 2009;6(1): 1-7.

24. Imlay JA. The mismetallation of enzymes during oxidative stress. Biol Chem. 2014;289(41): 28121-8. doi: 10.1074/jbc.R114.588814. [PubMed].

25. Grinenko UV, Zhuravel IA. [Quantitative determination of phenolic compounds in the leaves of garden spinach (Spinacia oleracea L.)]. The role of youth in the development of medical science: Proceedings of the XII Scientific and Practical Conference of Young Scientists and students of TSMU them. Abuali ibni Sino with international participation dedicated to the "Year of Youth", Dushanbe, April 28, 2017:292-293.380. Russian.

26. Grinenko UV, Zhuravel IA. [Determination of the quantitative content of organic acids in the leaves of garden spinach (Spinacia oleracea L.)]. Actual Problems of Modern Medicine and Pharmacy: Materials of the 69th Final Scientific Practical Conference of Students and Young Scientists. Vitebsk: Voronezh State Medical University, 2017: 611-612. Russian.

27. Moroz LV, Paliy IG, Tkachenko TV. [Introducing Enterosgel to a complex therapy of patients with a host of external hepatitis and intestinal dysbacteriosis]. Vnutrennaya meditsina. 2008;1(7): 11-8. Ukrainian.

28. Ogawa K, Suzuki K, Okutsu M, Yamazaki K, Shinkai S. [The association of elevated reactive oxygen species levels from neutrophils with low-grade inflammation in the elderly]. Immun Ageing. - 2008;5: 1-8. doi:10.1186/1742-4933-5-13.

29. Nykyforuk AYa, Fira LS, Lykhatskyi PH. [The extension of antioxidant power to the extract of spinach and leaf leaves on the model of tetrachloromethane fired ovens]. Med ta klin khim. 2018;20(4): 36-43. Ukrainian.

\section{Відомості про авторів:}

Никифорук А. Я. - асист. кафедри біохімії, фрармакології, фрізичних методів лікування 3 курсом аналітичної медицини, ДВНЗ «Ужгородський національний університет», Ужгород, Україна. E-mail: djsunray@gmail.com, ORCID 0000-0001-7590-4539.

Фіра Л. С. - д. біол. н., професор, завідувач кафредри фрармації ННІ ПО, Тернопільський національний медичний університет імені І. Я. Горбачевського МОЗ України, Тернопіль, Україна. E-mail: ludafira@ukr.net, ORCID 0000-00025325-0973.

Лихацький П. Г. - д. біол. н., професор кафедри медичної біохімії, Тернопільський національний медичний університет імені І. Я. Горбачевського МОЗ України, Тернопіль, Україна. E-mail: luhatsky@ukr.net, ORCID 0000-00020021-782X.

\section{Information about the authors:}

Nykyforuk A. Ya. - the assistant of the Biochemistry, Pharmacology, Physical Methods of Treatment with the Course of Analytical Medicine Department, Uzhhorod National University, Uzhgorod, Ukraine. E-mail: djsunray@gmail.com, ORCID 0000-0001-7590-4539.

Fira L. S. - DS (Biology), Professor, head of the Pharmacy Department, I. Horbachevsky Ternopil National Medical University, Ternopil, Ukraine. E-mail: ludafira@ukr.net, ORCID 0000-0002-5325-0973.

Lykhatskyi P. H. - DS (Biology), Professor, the Medcine Biochemistry Department, I. Horbachevsky Ternopil National Medical University, Ternopil, Ukraine. E-mail: luhatsky@ukr.net, ORCID 0000-0002-0021-782X. 